\title{
Artículos
}

\section{Knowledge Management and}

Innovation in Agricultural Organizations: An Empirical Study
in the Rural Sector of Northwest Mexico*

How to cite this article: Flores Lopez, J. G., Ochoa Jiménez, S., \& Jacobo Hernández, C. A. (2020). Knowledge management and innovation in agricultural organizations: An empirical study in the rural sector of Northwest Mexico. Cuadernos de Desarrollo Rural, I7. https://doi.org/ıO. III44/Javeriana.cdri7.kmia

Jose Guadalupe Flores Lopez ${ }^{\text {a }}$

Instituto Técnico de Sonora, México

Jgfloresıoo6@gmail.com

ORCID: https://orcid.org/0000-0002-6380-5135

Sergio Ochoa Jiménez

Instituto Técnico de Sonora, México

ORCID: https://orcid.org/0000-0003-I848-3760

Carlos Armando Jacobo Hernández

Instituto Técnico de Sonora, México

ORCID: https://orcid.org/0000-0002-8524-6258

DOI: https://doi.org/ro.III44/Javeriana.cdrı7.kmia

Received: 02 May 2019 I Accepted: II July 2020 I Published: 20 December 2020

${ }^{a}$ Corresponding author. Email: Jgfloresıoo6@gmail.com 


\begin{abstract}
:
Agricultural activity in the rural sector has been studied mainly in terms of technical questions regarding cultivation; however, the organizational aspects that generate added value, such as knowledge, have rarely been addressed. Therefore, the purpose of this paper is to investigate the relationship between knowledge management and innovation in rural agricultural organizations in northwestern Mexico. A questionnaire with composed of 36 items and a thorough interview was applied to seven leading organizations of the Yaqui Valley (YV). The results reveal a positive and significant relationship between knowledge management and innovation.
\end{abstract}

Keywords: rural sector, farmer's, correlation study.

\title{
Gestión del conocimiento e innovación en las organizaciones agrícolas: un estudio empírico en el sector rural del noroeste de México
}

\section{Resumen:}

La actividad agrícola en el sector rural ha sido estudiada principalmente en términos de cuestiones técnicas concernientes a los cultivos; sin embargo, los aspectos organizacionales que generan valor agregado, como el conocimiento, muy raras veces han sido abordadas. Por consiguiente, el propósito de este artículo es investigar la relación entre manejo del conocimiento e innovación en las organizaciones agrícolas rurales del noroccidente de México. Se aplicó un cuestionario compuesto de 36 ítems y una entrevista exhaustiva a siete organizaciones importantes del Valle del Yaqui (VY). Los resultados revelan una relación positiva y significativa entre manejo del conocimiento e innovación.

Palabras clave: sector rural, granjero, estudio de correlación.

\section{Introduction}

Over the last two decades, professionals and academics have redirected their work from organizations to the study of knowledge and results in relation to innovation. In addition, this field has become a multidisciplinary area of knowledge in which scientific knowledge can be generated (Kamasak et al., 20I6; Shafique, 20I3). In this sense, creating, adopting or adapting innovations in the rural sector has become complex and must be combined locally through tacit and implicit knowledge and, on ther other hand, derived from specialization through explicit knowledge (Esparcia, 2014). For this reason, studies regarding both themes in the agricultural sector worldwide have been reflected in various scientific articles highlighting technical characteristics (Ho et al., 2019; Totin et al., 2020), such as the knowledge and study of soils (Chenu et al., 2019; Techen et al., 2020), pest management (Abtew et al., 2016; Khan and Damalas, 2015) and various economic tools, strategies and models (Baloch and Thapa, 2016; Djanibekov et al., 2015; Dolinska and d'Aquino, 2016).

In Mexico, agricultural producers have also been studied, both in indigenous communities and in areas that have marked the history of land ownership in the country. The relevance tehreof is that these areas have a great cultural richness and important traditions, such as Chiapas, Oaxaca, Michoacán and Jalisco. Studies on supply and new crop varieties (Badstue et al., 2007; Bellon and Hellin, 20II; Honorato-Salazar and Sadhukhan, 2020), viability in agricultural production and utilization (Castillo et al., 2014; Cortez-Arriola et al., 2015), the study of soils (Sánchez-Osorio et al., 2017), and climatic conditions and ecological factors (Allende et al., 2016; Campos et al., 20I4) have been performed. 
Particular to northwestern Mexico, in the Yaqui Valley (YV), diverse researches have been conducted (Meza et al., 2004) regarding the management of water and soil chemical components, as well as bacteria in crops, (VillaRodríguez et al., 20I9; Meza-Montenegro et al., 20I2) irrigation and fertilizers (Millar et al., 20I8), remote sensing of crops (Lobell et al., 2003; Méndez-Barroso et al., 2008), and vulnerability to global warming (Lares-Orozco et al., 2016; Luers et al., 2003).

A literature review revealed little research in this sector with an organizational focus, specifically regarding the generation of empirical studies related to knowledge management $(\mathrm{KM})$ and innovation in the $\mathrm{YV}$, a sector where it is possible to generate contributions to knowledge. For this reason, this study seeks to determine the relationship between KM and innovation among the YV agricultural organizations.

\section{Literature Review}

\section{KM, Innovation and the Context of Agricultural Producer Organizations}

In the southern part of the State of Sonora, Mexico, there is a region known as the YV (figure I), that according to Naylor et al. (200I) is a region characterized by rapid economic and ecological changes. This valley consists of 235,000 irrigated hectares located between the Sierra Madre and the Gulf of California. Out of them, approximately 159,000 are used for wheat planting, accounting for $68 \%$ of the total agricultural land used for this crop, and making this state one of the main wheat producers and exporters in the country (Suárez, 20I2). According to the Agrifood and Fisheries Information Service (SIAP, 2020), the Yaqui Valley, mostly belonging to the influence area of the Cajeme Irrigation District, reported in 2019 a planted area of 227,273 hectares, accounting for $54.80 \%$ of the total planted area in the State of Sonora. 


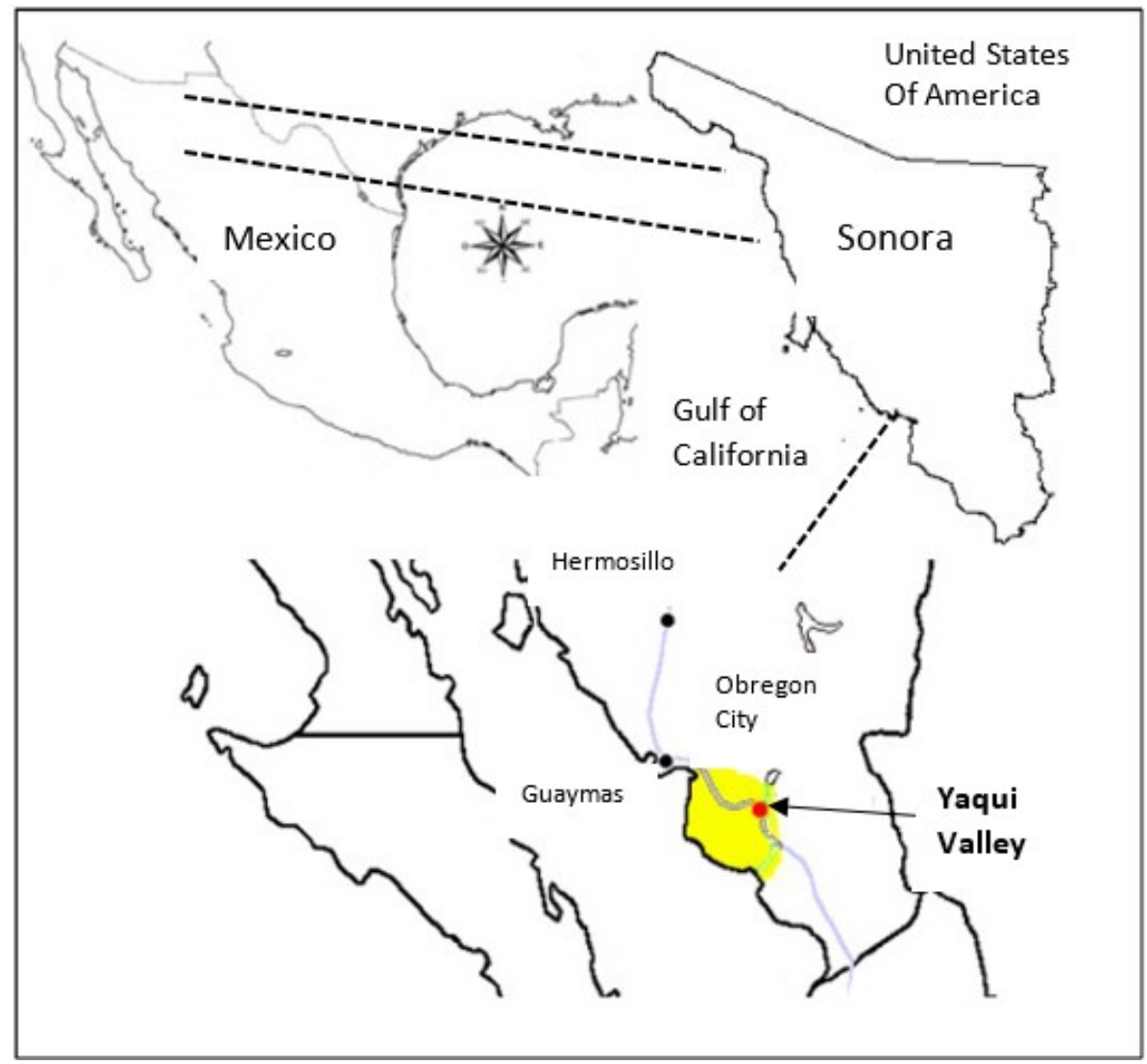

FIGURE 1.

LOCATION OF THE YV

Source: adapted from Meza-Montenegro et al. (2012)

\section{Theoretical Foundation of KM}

The origin of the study of knowledge dates back to ancient philosophy, with philosophers such as Socrates, Plato and Aristotle, whose foundations were knowledge, self-reflection and self-knowledge (Hessen, 20ro). In this sense, the study of knowledge has created a division to be understood. Dueck (200I) states that there are four types of established knowledge: episteme, focused on principles and laws; techne, that refers to technical knowledge; phronesis, or wisdom; and metis, that refers to skills and competencies.

This classification has not been enough since it does not fully explain the construction of knowledge among the people. Therefore, Polanyi (1966) presented a work focused on tacit knowledge to elucidate what type of knowledge makes a human being a thinking person; his conclusion was that human beings know more than they can say. On the other hand, changes in knowledge paradigms appear within organizations, and they begin their work with a view toward a knowledge society (Drucker, 1968). Subsequently, interest in the study of knowledge was not a topic specific to philosophy anymore and began to be researched also in the organizations. One of the first scholars and possibly the most notable was Ikujiro Nonaka, who focused his research from 1987 to 1995 on knowledge creation.

Different positions have emerged and have shaped other concepts of KM in the organizations. However, the reference they all used to support their ideas is Nonaka and Takeuchi (1995), who conceptualizes KM as a process of internalization and externalization of the individual. Tejedor and Aguirre (1998), Andreu and Sieber (1999), and Huang et al. (1999) see KM as a process to generate value and gain competitive advantages by reusing the knowledge 
already acquired. In a different case, Bueno (1999) states that KM is the function of planning and controlling the flows of knowledge in an organization and its environment. There are multiple models that have marked an evolution of the concept throughout history (table I).

TABLE 1 .

Models of KM

\begin{tabular}{lll}
\hline Year Model & Description \\
\hline & & $\begin{array}{l}\text { It is a proposal based on three fundamental } \\
\text { blocks for the management of knowledge that he } \\
\text { called pillars. Each pillar is a stage for the } \\
\text { management of knowledge, and on them exists a } \\
\text { base of creation, use and transfer of the } \\
\text { knowledge that is the support making fluent } \\
\text { within the organization. }\end{array}$
\end{tabular}

1995 Creating the knowledge by Nonaka \& Takeuchi

1999 Knowledge in Choo's organization

It shows the process in the form of a spiral, involving four ways of conversion: socialization (tacit and tacit knowledge, sharing experiences), articulation (from explicit to explicit, by telephone communication, meetings, documents, computer networks), by combination (from tacit to explicit, with the help of metaphors, analogies, creation of new concepts, hypotheses or models) and internalization (from explicit to tacit, entails shared mental models and know-how).

This proposal identifies the creation of knowledge in an individual way so that before reaching its capture element, the knowledge passes through a set of people at an organizational level. Therefore, the main elements of the model are the capture, innovation and distribution of knowledge.

This proposal arises based on the models of decision-making, common sense and knowledge creation. The organizations in their strategy are based on the construction of meaning, the creation of knowledge and the decision-making to generate actions within the organization.

1999 KM by Arthur Andersen 


\section{Views on Innovation}

According to Freeman (1982), lack of innovation causes that organizations cease to exist or operate because innovation is one of the keys to survival and the achievement of competitive advantages in the organizations in today's business world. From Drucker's (1985) perspective, innovation is the means whereby organizations run by innovative entrepreneurs can detect an opportunity to grow their business through an improvement and differentiation process.

Under the economic theory Schumpeter (1935) postulates that the economic development is explained through the innovative processes in the companies; hence, the result of the new combinations of the production factors are the main drivers of this development. In addition, according to this author, some elements favor this economic development: a) new goods (products), b) new production methods (processes), c) new markets, d) new inputs and, and e) new structures of industrial organization. This way, the capitalist system generates what is called creative destruction, so the capitalist society is in constant movement.

In 2005, the Organization for Economic Co-operation and Development (OECD) stated in the Oslo Manual that an innovation is the introduction of a new, or significantly improved, product or service, process, marketing method or organizational method in the internal practices of a company, the organization of the workplace or external relations. An innovative company, in terms of product / process, is a company that has introduced a new product or process, or has significantly improved during the period under study.

Knight (1967) defines innovation as the acceptance of a novel change for companies and their environment. Zaltman et al. (1973), in addition to Pavón and Goodman (1976), are considered to have made the first contributions to the concept of innovation as development, which is based on an idea combined with activities incorporated in a designated period of time and place, in the form of new products or improved processes, services, management techniques and organization. On the contrary, O'Brien and Shennan (20I0) claim that innovation is any thought, behavior or thing that is new because its quality factor is different from an existing one.

The concept of innovation has evolved over the years, mostly from an economic perspective, and has had an impact on the development and growth of countries (figure 2).

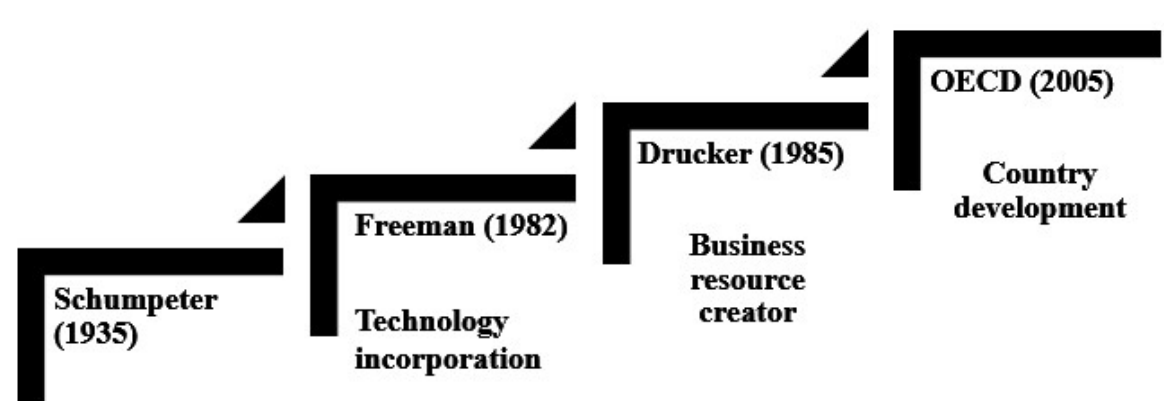

Economics

FIGURE 2.

Chronology of CONTRibutions to THE CONCEPT OF INNOVATion

SOURCE: OWN WORK

The COTEC Foundation for Technological Innovation (2007) defines innovation from the perspective of the organizations as "any change caused by the same company that is based on knowledge and generates value" (p. i7). Additionally, it states that the change is the path to generate an innovation, but another important element is knowledge which becomes the basis for creating such change.

Empirical Studies Related to Study Variables 
Based on the question introduced in the previous chapter, researchers highlight the presence of empirical evidence between the construction of knowledge and innovation as a result from the increased performance through alliances. There are also researches that focus on elucidating the relationship between the previous variables. These different contributions to the context, like the type of company and those related to other variables, account for this phenomenon. An example is the statement that strategic alliances favour knowledge and innovation management (Briones-Peñalver et al., 2020), customer relationship and knowledge management, which are preceded by the innovation capacity (Fidel et al., 20I6). In particular, knowledge management appears as a mediator between internal networking and ambidextrous innovation (Cabeza-Pullés et al., 2019); between the internationalization of SMEs and innovation performance (Ferraris et al., 2019); between knowledge-oriented leadership and open innovation (Naqshbandi and Jasimuddin, 20I8). However, between transformational leadership and teaching and learning innovation it does not play the role of mediator (Supermane, 2019). One of the most recent studies focuses on organizational learning as a mediator of the relationship between knowledge management and sustainable organizational innovation (Abbas et al., 2020).

Several studies aim to confirm the relationship between these two variables, where the results are positive and significant (Acosta-Prado et al., 2020; Al-Dmour et al., 2020; Hock-Doepgen et al., 2020; Nagano and Iacono, 2019; Yousaf and Ali, 2018; Mejía et al., 2016; Obeidat et al., 2016; Dos Santos-Ferreira and Santos, 2014; JiménezJiménez et al., 2014), particularly in SMEs (Väyrynen et al., 20I7; Saini and Bhargava, 2020) and in higher education institutions (Elmorshidy, 2018; Sadeghi Boroujerdi et al., 2019). Moreover, other studies show the influence of knowledge management on innovation and the effect on performance (Singh et al., 2019; Mardani et al., 2018; Migdadi et al., 2017; Marques et al., 2016).

The idea that the process of knowledge management positively and significantly impacts innovation is reiterated. Nevertheless, if companies are to have better performance, it is suggested that they rely on a incentive system for knowledge activities (Omoush, 20I8). A government sector study found that innovation performance decreases when the improvement of knowledge is rewarded (Susanty et al., 2019); perhaps this divergence is the result from not calculating a break-even point, since investments in knowledge management tend to have a maximum effect, from which innovation slows down (Teixeira et al., 2018).

The study of knowledge and innovation in the agricultural sector is limited and only two cases stand out. In the first one, the components of knowledge management have a significant positive effect on organizational innovation in the agricultural sector of the Khuzestan Province (Kaabi and Roosta, 2018). In agri-food companies, IT-based knowledge exploitation capabilities were found to be enabling for open innovation strategies (Cillo et al., 2019). Therefore, based on this referenced work, the following hypotheses are proposed herein:

H. KM and innovation in agricultural organizations are positively and significantly related.

H2. Greater KM generates greater innovation in agricultural organizations.

\section{Methodology}

\section{Participants}

Participants in this study were agricultural producers in YV who sow a variety of crops, such as wheat, maize, safflower, manure and cotton. Some of them belong to agricultural credit unions, whereas others are independent producers who settle their expenses using their own financing. In the first instance, the population was limited 
to four agriculture credit unions. However, the universe encompassed all agricultural producers belonging to the $\mathrm{YV}$, as describeb above.

Regarding the data collection, a total of 95 subjects were included (table 2). Micro-organizations account for $79 \%$ of the subjects, and the remainder is taken as small and medium enterprises, as defined by the Official Gazette of the Federation in 2009 .

TABLE 2.

NuMBER OF PEOPLE SURVEYED BY POST

\begin{tabular}{lrr}
\hline Market Stall & Frequency & Percentage \\
\hline Producer (Farmer) & 64 & 65 \\
Administrators & 26 & 29 \\
Technical Supervisors & 5 & 6 \\
\hline Total & 95 & 100 \\
\hline
\end{tabular}

Source: own work

Based on table 2, it should be noted that approximately 20 different employment positions were captured; however, it was decided to group them into three large sets. The first group are the farmers-producers, who are mostly individuals with business activities completely dedicated to the agricultural activity. It should be noted that this group also includes shareholders of common land, whose distinctive feature is a low agricultural production due to the extent of area they own. The second group includes field managers, managerial staff of legal entities, and production and/or field managers. The last group includes floor supervisors, technicians and production supervisors.

A large percentage of the sample completed only their basic education; however, a significant number completed earned any higher education degree, including graduate studies (table 3).

TABLE 3.

Academic degree of the sample

\begin{tabular}{lrr}
\hline Schooling & Frequency & Percentage \\
\hline Basic level & 38 & 36.5 \\
High school & 21 & 23.5 \\
Bachelor's or engineering degree & 29 & 32.9 \\
Graduate & 7 & 7.1 \\
\hline Total & 95 & 100 \\
\hline
\end{tabular}

Source: own work

In table 3, as in the previous one, the academic grades were grouped, where the category of basic education corresponds to elementary and junior high school levels. However, the level to be highlighted is that of undergraduate degree. Approximately $33 \%$ of the sample has a bachelor or engineering degree, which indicates that agricultural producers seek academic improvement. The graduate category includes four subjects with master's degrees and two with doctorates. 


\section{Instruments}

The questionnaire design was a five-point Likert-scale instrument that consisted of 36 items in total. The items were as follows: for the KM variable, I4 items were considered (I-I4). These were based on theory (Bueno, I999; Nonaka and Takeuchi, 1995) and some of the instrument applied by Jones (2009). For the innovation variable, a total of 22 items (15-36) that explained the dimensions of products and processes, technology and collaborative strategic development were obtained. Some items in this section were taken from theory (OCDE, 2005), and the remainder from the instrument applied by Goktan (2005).

Another instrument used herein was a structured interview guide, which was consisted of five elements: I. An interview script containing the explanation and purpose of the application; 2. General context, that includes the origin, growth and current situation of the organization; 3. Knowledge management, where the dimensions of knowledge creation, knowledge application and knowledge transfer were generalized; 4. Innovation, asking about products and processes as well as technology and development.

In total, seven in-depth interviews were implemented as follows: three natural persons and four legal persons with these characteristics: low and high planting surface, and active members of agricultural producer associations (table 4).

\section{Characteristics}

Credit union partner and/or producer organizations. 


\section{Procedure}

Information was gathered to support the study variables. Once the information was selected, it was decided to use the Likert-scale format with five points to generate response options. After the structure was defined, each item was formulated with its respective theoretical and empirical support. Once the instrument was structured, it was validated by experts. The pilot test was applied to 17 agricultural producers. Based on the most outstanding data in the pilot test, the structure of items and the comprehension by the respondents were analyzed. According to the results from the pilot test, the instrument was applied, both individually and, in some cases, through producer groups in visits to their workplace. Ninety questionnaires were answered. A database was built with the gathered data, taking care to not make typos in order to avoid data corruption. Then, with the database based on the 95 respondents, the statistical analyses and tests described below were performed. According to the application of the interview, it was observed in the pilot test that the guiding questions were appropriate; however, it was necessary to guide the producer to answer essential issues since it was detected that the objective of obtaining valid information can be diverted by talking about topics not focused on the main search. Once the information with audio evidence was obtained, the data was processed. According to this, the Microsoft Word tool was utilized to write the original audios obtained during the interviews without omitting any data and content information. Next, a table analysis was created for each question with its dimensions, in which textual quotations were extracted and could help to interpret the quantitative results.

\section{Results}

The internal validity of the instrument was determined using the database through tests for normality (asymmetry and kurtosis), and the consistency of the internal factors of the instrument was tested with an exploratory factor analysis (tables 5 and 6).

TABLE 5 .

Results of Factor analysis: KMO-Bartlett-Chi-VARiance

\begin{tabular}{lr}
\hline Element & Percentage \\
\hline KMO & 0.833 \\
Bartlett test & 0.000 \\
Square Chi & 1311.87 \\
Total Variance Explained & 64 \\
\hline
\end{tabular}

Source: own work 
TABLE 6

Matrix AND ROTATED COMPONENT MODEL

\begin{tabular}{|c|c|c|c|}
\hline \multirow{2}{*}{ Item } & \multicolumn{2}{|c|}{ Factor Loadings } & \multirow{2}{*}{ Communalities } \\
\hline & 1 & 2 & \\
\hline NNOl & 0.697 & 0.307 & 0.681 \\
\hline INNO2 & 0.768 & 0.261 & 0.730 \\
\hline INNO4 & 0.795 & 0.120 & 0.634 \\
\hline INNO7 & 0.706 & -0.038 & 0.484 \\
\hline INNO8 & 0.875 & 0.112 & 0.683 \\
\hline INNO9 & 0.832 & 0.268 & 0.759 \\
\hline INNOI0 & 0.766 & 0.198 & 0.667 \\
\hline INNO13 & 0.557 & 0.239 & 0.564 \\
\hline INNO19 & 0.737 & 0.062 & 0.592 \\
\hline KM1 & 0.326 & 0.674 & 0.701 \\
\hline KM2 & 0.302 & 0.784 & 0.758 \\
\hline KM3 & -0.088 & 0.688 & 0.457 \\
\hline KM5 & 0.268 & 0.697 & 0.681 \\
\hline KM7 & 0.146 & 0.855 & 0.701 \\
\hline KM8 & 0.076 & 0.870 & 0.656 \\
\hline KM9 & 0.093 & 0.710 & 0.568 \\
\hline KM10 & 0.171 & 0.635 & 0.594 \\
\hline KM11 & 0.302 & 0.613 & 0.723 \\
\hline
\end{tabular}

Source: own work

Table 5 presents the $\mathrm{KMO}$ (Kaiser, Meyer and Olkin) test results to search for correlations between the variables. The KMO test indicates a correlation when the result is close to I. In this case, 0.833 is remarkable and can be deemed a partial correlation of the variables. The results of Bartlett's sphericity test are presented in the same table 5 . These results indicate significance because the value is less than 0.05 , meaning that the null hypothesis is rejected and factorial analysis can be applied.

Another criterion approved in the internal validation is shown, as with the principal components (PC) extraction method, there is clarity in the extraction of the internal factors of the instrument when selecting those items that are greater than 0.333 and are not grouped into more than two factors. In the end, the three main components explain $64 \%$ of the total variance of the variables. 
As observed, in the end, the model consists of $\mathrm{I} 8$ items grouped into two factors, all above 0.333 and loading clearly onto one factor. The grouping was performed through the Varimax rotation method and the CP extraction method. Therefore, the previous structure is the one validating that the items of the instrument are highly correlated with each other. Once the factor analysis was performed, it was proposed to review the reliability of the items covering the three variables of the instrument (table 7). Due to these facts, the database was applied again, and the items were subjected to the Cronbach's alpha test.

TABLE 7.

ReLiability of VARIABLES

\begin{tabular}{|c|c|c|}
\hline Variable & $\begin{array}{c}\text { Number of } \\
\text { Elements }\end{array}$ & Cronbach's Alpha \\
\hline KM & 9 & 0.907 \\
\hline Innovation & 9 & 0.916 \\
\hline
\end{tabular}

Source: own work

Once the database was analyzed in the system, the corresponding statistical tests were performed. In the first instance, it is crucial to report the results regarding the hypotheses. The hypotheses proposed in the theoretical section of the project are accepted:

H. KM and innovation are positively and significantly related.

$\mathrm{H}_{2}$. Greater KM generates more innovation.

To obtain the above results, a correlation test was performed (table 8). From this test, it is evident that KM and innovation have a correlation percentage greater than $44 \%$, which indicates a significant relation between the variables at a significance level of $0.0 \mathrm{I}$, being greater than zero and positive.

TABLE 8.

Correlation between KM and INNO

\begin{tabular}{lrrrrr}
\hline Variable & $\mathbf{N}$ & $\mathbf{M}(\%)$ & $\mathbf{S D}(\%)$ & $\mathbf{1}$ & $\mathbf{2}$ \\
\hline KM & & & & & \\
Innovation & 90 & 3.59 & 0.85 & -- & \\
\hline
\end{tabular}

\footnotetext{
Source: own work

Note: Significant at .or (2 tailed).
}

It should be noted that table 8 demonstrates an effective relationship, and this is considered acceptable within the parameters noted by Pearson, as the percentage presented explains $20 \%$ of the shared variance among its elements. Therefore, there are elements to consider within the agricultural organizations that underpin this relationship. For example, the items KMı and KM2, which quantify whether the producers have activities for the generation and acquisition of knowledge, present an average value above 3.8, with which the data confirm a level of response according to the activities of generation and acquisition that relates to item INNOIg that, in turn, shows the same tendency to generate changes in the processes and products as time passes.

According to this last statement, in the YV the activities that generate and provide knowledge, and favor innovation are mainly they training by third parties, i.e., an empirical knowledge already proven as mentioned by the interviewee 4 and 7, respectively; "the little, medium or regular knowledge I acquired in the development 
bank, and whether or not you want in the field, where you become a professional, this does not happen in school or books" $\left(\mathrm{I}_{4}\right)$; "we have been involved in several events, in various training and knowledge transmission forums by the Secretariat of Agriculture, Livestock, Hydraulic Resources, Fishing (SAGARHPA) Trusts Instituted in Relation to Agriculture (FIRA) and Rural Finance" ( $\left.\mathrm{I}_{7}\right)$. Consequently, the relationship between the variables shows an influence that the KM generates on innovation; it is observed in detail with a linear regression (table 9).

TABLE 9.

LiNEAR REGRESSION BETWEEN KM AND INNO

\begin{tabular}{lrrrrr}
\hline Variable & B & $95 \%$ CI & B & t & p \\
\hline Innovation & & & & & \\
& 0.388 & {$[0.219-0.557]$} & 0.448 & 4.56 & 0.001 \\
\hline
\end{tabular}

\author{
Source: own work \\ Note: $\mathrm{R}_{2}=.20(\mathrm{~N}=95, \mathrm{p}<.00 \mathrm{I}) . \mathrm{CI}=$ confidence interval for $\mathrm{B}$.
}

In particular, the results shown in table 9 above indicate that KM predicts $20 \%$ of innovation in YV agricultural organizations; therefore, it is estimated that the remaining $80 \%$ is dispersed in other variables not considered in this study. This result stresses the importance of sharing and transferring knowledge so that innovation in YV may increase in terms of new crop varieties and new techniques offered by the talks promoted by governmental agencies.

In addition, what prevails is getting to know new technologies in these talks and conferences, in some cases to acquire and modify them: "there are very modern four-row tractors and we made six-furrow seeders, then it is faster" $\left(I_{3}\right)$; and in some aspects related to product packaging, innovations are also highlighted to reduce costs: "we received that machine, but we adapted it to what we wanted, is currently a band that is totally different with which we could decrease a time of $80 \%$ to what normally makes a normal band" $\left(\mathrm{I}_{7}\right)$. The modification and relation to the processes are highly oriented to the production process in which the INNO 13 item is highlighted. It presents an average value higher than 3.8, which creates a trend in the agricultural organizations in the Yaqui Valley. In other words, there are new ways to improve your production flexibility.

Therefore, it is important to consider the fundamental aspects that generate the results of the knowledge management dimensions: creation and acquisition, transfer and application, which are related to the innovation dimensions: products, processes and services, technology and development, which can be interpreted as follows:

The creation and acquisition of knowledge in the Yaqui Valley is largely due to the training and practice of the know-how, which is induced by a transfer of knowledge in various areas as mentioned by interviewees 4, 5 and 6: "with the example, the daily practice and the mechanization in the field" ( $\left.\mathrm{I}_{5}\right)$; "I studied, that is why I prepared myself, I don’t want to be boastful but everything we do we must be prepared” (I6); "I acquired the few, medium or regular skills in development banking, and in the daily basis" $\left(\mathrm{I}_{4}\right)$; "With technical advice, there were programs related to technical advice that at the time they were applied by the rural bank and generated the technical knowledge for the agriculture management” $\left(\mathrm{I}_{5}\right)$. The training by third parties is then highlighted as an essential factor in the explanatory model of the relationship between both variables.

Products, processes and services have been innovated through the acquisition of technology. In this case, crop varieties, new planting techniques and changes in machinery and process development were referred to by the interviewees I, 2 and 6: "there are several products that are derived from this. First is the plant, where we are working on extraction of essential amino acids for insect repellents", "in the mechanical part or harvest there is not a single company or person in the world that harvests mechanically as we do" ( $\left.\mathrm{I}_{\mathrm{I}}\right)$; "the changes were related to the addition of foliar fertilizer” ( $\left.\mathrm{I}_{2}\right)$; "I have diversified to other types of crops, such as corn, safflower, sesame, beans. Looking 
for the optimization of both financial and machinery resources, because if we are going to plant in large areas we need many elements for large areas" (I6).

Consequently, with the two previous aspects, factors directly involved in that relationship are identified: training by third parties, transference and adaptation through informal talks between the producers. "There are producers who know a lot, who know much more than myself, who I have a lot of respect for, and whom I have learned" $\left(\mathrm{I}_{4}\right)$; the family itself, creator of knowledge: "when my father started to prepare the land for some crop I was always attentive to see how he did it, then you learn and improve it" $\left(\mathrm{I}_{2}\right)$; in addition, the family is confirmed as a source of ideas that are transmitted by generations "my father is from the culture of work and effort that he inherited them from his grandfather, which is his dad, and then he would be my grandfather; hence, I have had patterns that I have copied them, this way we transmit the knowledge" $\left(\mathrm{I}_{4}\right)$.

All the foregoing, after a deep analysis, provides a broader picture on how knowledge is managed in the YV and, in turn, provides elements that transform into innovative ideas that relate to and impact the regional economy and directly interfere in a constant change reflected in production techniques. This is an essential part of the process innovation. Similarly, the improvement in business methods leads to the generation of additional services by encouraging the introduction of new markets and the generation of new products that are presented through the explanatory model (figure 3).

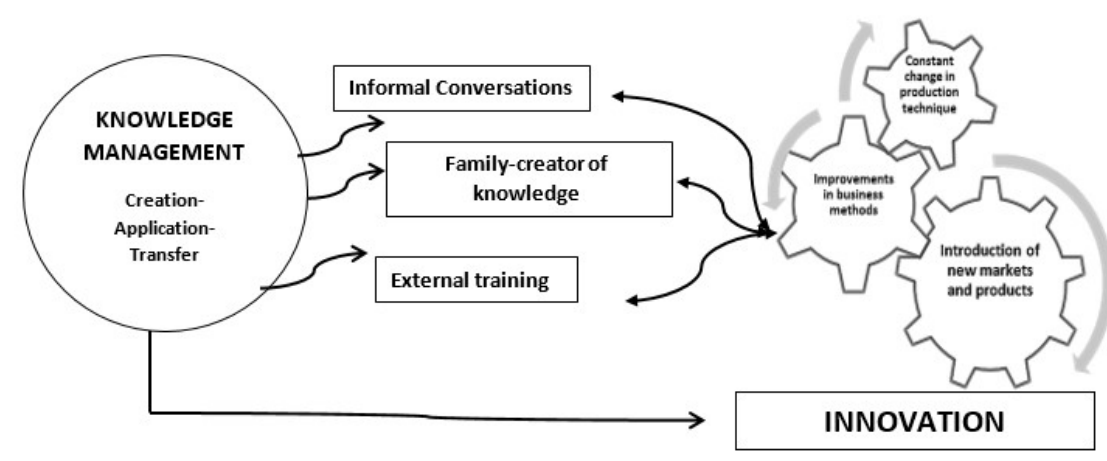

FIGURE 3.

Analysis of the Relationship betweEn KM and InNovation In the VY

SOURCE: OWN WORK

\section{Discussion}

According to the main findings presented herein, it is necessary to detail the most salient discussions from an empirical perspective. To do so, the main elements of the variables researched in other agricultural and rural areas of the world are presented using different methodologies.

The generation of knowledge through multiple sources of information among the small agricultural producers of the districts of Kenya is what Munyua and Stilwell (2010) emphasize in their quantitative and qualitative study. Using a sample of 224 producers in the districts making up the local agricultural system and several meetings through focus groups, they determined that the labor links with the other producers are weak. However, the groups were effective in promoting and expanding new technologies, innovation and improved cultivation methods. This situation is similar to what is occurring now in the YV in the sense that agricultural producers transfer ideas through informal talks and, therefore, there is an accurate communication of information to generate their own knowledge. From the same perspective, Rees et al. (2000) determined that the main sources of knowledge that 
small producers have in five of the seven districts of Kenya are local ones, such as neighbors, families, markets, and community-based organizations. Similar to the above, in the YV the family plays a fundamental role in the management of information to generate knowledge, since the YV has given all authority to the collective ejido producers (composed by families) as their only means to increase the standard of living of the peasants and their families belonging to these working groups (Cárdenas-García, 2016).

In the case of innovation in agriculture, now it is pertinent to discuss the work by Dolinska and d'Aquino (2016) carried out in agricultural cooperatives in France, who performed a qualitative study of agricultural cooperatives in France to examine the role of communities (CoPs) of farmers according to the innovation process. Their findings are interesting because they demonstrate that farmers belonging to these communities are better trained for innovation than those who work individually with the expert's support. In YV occurs the opposite: farmers are individualistic and do not use groups to strengthen their innovation processes but, rather, as a strategy to link their membership to a union or society through financing strategies or government resources.

In the same way, it is necessary to share knowledge about the innovation process among farmers, the scope of doing a systematized work of innovation and its benefits. According to this, in YV happens something different, institutions specializing in research and improvements in product and technical processes are trying to work with producers to give them new practices, as the interviewee 6 considers: "there is innovation in crop diversity, all people are given training, talks about marketing , costs...” (I6). However, they are, themselves, the ones creating barriers to the entry of that new knowledge in favor of innovation, as told by the interviewee 4 : "there are producers who do not approach because they say to me no one will tell me what I have to do" $\left(\mathrm{I}_{4}\right)$.

To continue the discussion of the findings, it is pertinent to reevaluate the empirical evidence for the relationship of KM and innovation. On this regard, Dos Santos-Ferreira and Santos (2014) confirm this fact through their study in Portugal, in which they determine the influence of KM on innovation practices; the knowledge creation dimension is the most important factor contributing to innovation in these organizations. In this sense, as in YV and for agricultural producers, knowledge creation is a fundamental element, and statistical data above average (3.8) are relatively consistent with this research.

In the same vein, Moos et al. (2013) present a research on manufacturing companies; they determine an optimal relation between innovation and technological knowledge and emphasize the strategy of applying that knowledge as a determinant and important element for the success in innovation. Regarding the organizations in YV also prove to be congruent with this fact, as the practices and management of the new technology are elements favoring innovation because the organizations agree that they are the first to introduce new methods and technologies in YV.

\section{Conclusions}

Regarding the final contributions, it is concluded that the research objective is satisfactorily attained. On one hand, the correlation between the variables of the study is positive and significant. So it can be said that in YV, agricultural producers in the process of KM (creation, acquisition and transfer of knowledge) will also be considered innovative in terms of any innovation type.

On the other hand, the influence of KM on the innovation was acceptable, as the activities of generation of knowledge are related to the activities of innovation, although not strongly. Nevertheless, a correlation exists and can be considered a preliminary contribution of this study. With these results, it is necessary to underline the contribution of this study to the theory, taking into account the assumptions used to explain that KM influences innovation. In this sense, it is stated that, at least in $\mathrm{YV}$, the influence is positive and significant for the agricultural producers. 
Another important aspect to consider is the empirical contribution of this work to future studies, as this work can serve as a reference in organizational research for the agricultural sector, and particularly in YV. For this reason, we must underline the great gap existing so far and the new challenges that require working empirically with studies related to the variables of organizational analysis in a sector that usually is characterized by technical products.

It is extremely important to mention that $\mathrm{YV}$ is an unexplored area in the organizational sphere. The agricultural producer organizations found in this territory are covered by different lines of research mentioned in the field work, including the family, sustainability, climatic changes, governmental policies, modernity and tradition, among others.

As far as the family is concerned, it was observed that family is the first source to get information for the construction of knowledge and is involved in the societies created with strategic purposes. This way, most of the producers legally establish their farming societies with family members to obtain governmental funding and support.

It is necessary to take into account different possible methods for strengthening the present study. First, we can study the YV with the same variables but using different instruments or harvesting techniques. It would be interesting to create focus groups to debate the ideas and questions that may arise from the results and contrast them with the results from researches conducted at a global extent, thus obtaining benefits for the productive subjects involved in this sector.

On the other hand, it is necessary to include a greater number of participants to obtain opinions and data that provide us with a closer look at the organizational reality in which the agricultural organizations of the YV operate. It is possible that through academic and governmental partnering, some work could be performed to achieve the goal of covering the majority of the researched sector.

Regarding future researches, it is important to include a study to explore the family topic. The succession of agricultural families in YV is a topic that will allow diverse perspectives and will complement this research, especially regarding the values, customs and traditions attached to the cultural variable. This claim is supported by the fact that more than $80 \%$ of the land planted in the agricultural sector belongs to common land sectors, whose legislation is mainly made up of families.

\section{References}

Abbas, J., Zhang, Q., Hussain, I., Akram, S., Afaq, A., \& Shad, M. A. (2020). Sustainable innovation in small medium enterprises: The impact of knowledge management on organizational innovation through a mediation analysis by using SEM approach. Sustainability, I2(6), 2407. https://doi.org/I0.3390/sui2062407

Abtew, A., Niassy, S., Affognon, H., Subramanian, S., Kreiter, S., Garzia, G. T., \& Martin, T. (2016). Farmers’ knowledge and perception of grain legume pests and their management in the Eastern province of Kenya. Crop Protection, 87, 90-97. https://doi.org/I0.1016/j.cropro.2016.04.024

Acosta-Prado, J. C., Navarrete, J. F. F., \& Tafur-Mendoza, A. A. (2020). Relationship between conditions of knowledge management and innovation capability in new technology-based firms. International Journal of Innovation Management, 2150005-I. https://doi.org/I0.II42/Si363919621500055

Al-Dmour, A., Al-Dmour, R., \& Rababeh, N. (2020). The impact of knowledge management practice on digital financial innovation: The role of bank managers. VINE Journal of Information and Knowledge Management Systems, ahead-of-print(ahead-of-print). https://doi.org/I0.II08/VJIKMS-oI-2020-0006

Allende, T. C., Mendoza, M. E., Pérez-Salicrup, D. R., Villanueva-Díaz, J., \& Lara, A. (2016). Climatic responses of Pinus pseudostrobus and Abies religiosa in the monarch butterfly biosphere reserve, central Mexico. Dendrochronologia, 38, 103-116. https://doi.org/10.1016/j.dendro.2016.04.002 
Andersen, A. (1999). El Management en el Siglo XXI. Granica.

Andreu, R., \& Sieber, S. (1999). La gestión integral del conocimiento y del aprendizaje. Economía Industrial, (326), 63-72. https://www.mincotur.gob.es/Publicaciones/Publicacionesperiodicas/EconomiaIndustrial/Re vistaEconomiaIndustrial/326/RAFAEL\%20ANDREU.pdf

Badstue, L. B., Bellon, M. R., Berthaud, J., Ramírez, A., Flores, D., \& Juárez, X. (2007). The dynamics of farmers' maize seed supply practices in the Central Valleys of Oaxaca, Mexico. World Development, 35(9), 1579-1593. h ttps://doi.org/I0.IoI6/j.worlddev.2006.05.023

Baloch, M. A., \& Thapa, G. B. (2016). The effect of agricultural extension services: date farmers' case in Balochistan, Pakistan. Journal of the Saudi Society of Agricultural Sciences, I7(3). http://dx.doi.org/10.1016/j.jss as.2016.05.007

Bellon, M. R., \& Hellin, J. (20II). Planting hybrids, keeping landraces: agricultural modernization and tradition among small-scale maize farmers in Chiapas, Mexico. World Development, 39(8), I434-I443. https://doi.org/I $0.1016 / j . w o r l d d e v .2010 .12 .010$

Briones-Peñalver, A. J., Bernal-Conesa, J. A., \& de Nieves Nieto, C. (2020). Knowledge and innovation management model. its influence on technology transfer and performance in spanish defence industry. International Entrepreneurship and Management Journal, I6(2), 595-615. https://doi.org/10.1007/s11365-019-00577-6

Bueno, E. (1999). La gestión del conocimiento en la nueva economía en gestión del conocimiento y capital intelectual. Experiencias en España. IU Euroforum Escorial, San Lorenzo del Escorial.

Cabeza-Pullés, D., Fernández-Pérez, V., \& Roldán-Bravo, M. I. (2019). Internal networking and innovation ambidexterity: The mediating role of knowledge management processes in university research. European Management Journal, So263-2373(19), 30152-5. https://doi.org/I0.1016/j.emj.2019.12.008

Campos, M., Velázquez, A., \& McCall, M. (2014). Adaptation strategies to climatic variability: a case study of small-scale farmers in rural Mexico. Land Use Policy, 38, 533-540. https://doi.org/10.1016/j.landusepol.2013. I2.017

Cárdenas-García, N. (2016). Movimiento campesino y oportunidades de cambio político y social. La experiencia del Valle del Yaqui (1920-1950). Estudios de historia moderna y contemporánea de México, (52), 69-87. https://doi.o $\mathrm{rg} / \mathrm{I0.1016/j}$.ehmcm.2016.06.002

Castillo, Y. B. V., Pritchard, H. W., Frija, A., Veettil, P. C., Sanchez, J. A. C., van Damme, P., \& van Huylenbroeck, G. (20I4). Production viability and farmers' willingness to adopt Jatropha curcas L. as a biofuel source in traditional agroecosystems in Totonacapan, Mexico. Agricultural Systems, I25, 42-49. https://doi.org/I0.I0I6 /j.agsy.2013.12.003

Chenu, C., Angers, D. A., Barré, P., Derrien, D., Arrouays, D., \& Balesdent, J. (2019). Increasing organic stocks in agricultural soils: Knowledge gaps and potential innovations. Soil and Tillage Research, I88, 4I-52. https:// doi.org/10.1016/j.still.2018.04.0II

Choo, C. W. (1999). La organización inteligente: el empleo de la información para dar significado, crear conocimiento y tomar decisiones. Oxford University Press.

Cillo, V., Rialti, R., Bertoldi, B., \& Ciampi, F. (2019). Knowledge management and open innovation in agri-food crowdfunding. British Food Journal, I2I(2), 242-258. https://doi.org/10.1108/BFJ-07-2018-0472

Cortez-Arriola, J., Rossing, W. A. H., Massiotti, R. D. A., Scholberg, J. M. S., Groot, J. C. J. and Tittonell, P. (2015). Leverages for on-farm innovation from farm typologies? An illustration for family-based dairy farms in north-west Michoacán, Mexico. Agricultural Systems, I35, 66-76. https://doi.org/I0.I0I6/j.agsy.20I4.I2.005 
Djanibekov, N., Djanibekov, U., Sommer, R., \& Petrick, M. (2015). Cooperative agricultural production to exploit individual heterogeneity under a delivery target: the case of cotton in Uzbekistan. Agricultural Systems, I4I, I-13. http://dx.doi.org/10.1016/j.agsy.2015.09.002

Dolinska, A., \& d'Aquino, P. (2016). Farmers as agents in innovation systems. Empowering farmers for innovation through communities of practice. Agricultural Systems, I42, I22-130. https://doi.org/10.1016/j.agsy.2015.II.009

Dos Santos-Ferreira, V. H., \& Santos, A. (2014). The Impact of Knowledge Management in Innovation Performance in the Leiria Region. In European Conference on Intellectual Capital, p. 24. Academic Conferences International Limited.

Drucker, P. F. (1968). The Age of Discontinuity Guidelines to our Changing Society. Harper \& Row.

Drucker, P. F. (1985). Innovation and Entrepreneurship: Practice and Principles. Harper \& Row.

Dueck, G. (200I). Views of knowledge are human views. IBM Systems Journal, 40(4), 885-888. https://doi.org/I0.I I $47 / \mathrm{sj} .404 .0885$

Elmorshidy, A. (2018). The impact of knowledge management systems on innovation: An empirical investigation in kuwait. VINE Journal of Information and Knowledge Management Systems, 48(3), 388-403. https://doi.org/I0.I I08/VJIKMS-12-2017-0089

Esparcia, J. (20I4). Innovation and networks in rural areas. An analysis from European innovative projects. Journal of Rural Studies, 34, I-I4. https://doi.org/10.1016/j.jrurstud.2013.12.004

Ferraris, A., Giachino, C., Ciampi, F., \& Couturier, J. (2019). R\&D internationalization in medium-sized firms: The moderating role of knowledge management in enhancing innovation performances. Journal of Business Research, in press https://doi.org/10.1016/j.jbusres.2019.11.003

Fidel, P., Cervera, A., \& Schlesinger, W. (20I6). Customer's role in knowledge management and in the innovation process: Effects on innovation capacity and marketing results. Knowledge Management Research E Practice: SPECIAL ISSUE: Knowledge Management and Relationships in SMEs, I4(2), 195-203. https://doi.org/I $0.1057 / \mathrm{kmrp} .2015 .19$

Freeman, C. (1982). The economics of industrial innovation. MIT Press.

Fundación Cotec para la Innovación Tecnológica [Cotec]. (2007). La persona protagonista de la innovación. Cotec.

Goktan, A. B. (2005). The Role of Strategy in the Innovation Process: A Stage Approach. University of North Texas Denton.

Hessen, J. (2010). Teori\# a del conocimiento. Panamericana Editorial.

Ho, K. L. P., Nguyen, C. N., Adhikari, R., Miles, M. P., \& Bonney, L. (2019). Leveraging innovation knowledge management to create positional advantage in agricultural value chains. Journal of Innovation $\&$ Knowledge, 4(2), II5-I23. https://doi.org/I0.1016/j.jik.2017.08.00I

Hock-Doepgen, M., Clauss, T., Kraus, S., \& Cheng, C. (2020). Knowledge management capabilities and organizational risk-taking for business model innovation in SMEs. Journal of Business Research. https://doi.o $\mathrm{rg} / \mathrm{I0} .1016 / \mathrm{j} . j$ busres.2019.12.00I

Honorato-Salazar, J. A., \& Sadhukhan, J. (2020). Annual biomass variation of agriculture crops and forestry residues, and seasonality of crop residues for energy production in Mexico. Food and Bioproducts Processing, II9, I-I9. https://doi.org/I0.I0I6/j.fbp.2019.10.005

Huang, K. T., Lee, Y., \& Wang, R. (1999). Quality Information and Knowledge. Prentice Hall, Upper Saddle River.

Jiménez-Jiménez, D., Martínez-Costa, M., \& Sanz-Valle, R. (2014). Knowledge management practices for innovation: a multinational corporation’s perspective. Journal of Knowledge Management, I8(5), 905-918. https:/ /doi.org/10.1108/JKM-06-2014-0242 
Jones, M. B. (2009). Organizational Culture and Knowledge Management: An Empirical Investigation of U.S. Manufacturing Firms (Order No. 3388995),(doctoral dissertation). Nova Southeastern University.

Kaabi, A., \& Roosta, K. (2018). Promoting organizational innovation among agricultural extension experts: The role for knowledge management. International Journal of Agricultural Management and Development, 8(3), 42I-43I. https://doi.org/10.22004/ag.econ.292550

Kamasak, R., Yavuz, M., Karagulle, A. O., \& Agca, T. (2016). Importance of strategic flexibility on the knowledge and innovation relationship: an emerging market study. Procedia - Social and Behavioral Sciences, 229, I26-132. h ttps://doi.org/10.1016/j.sbspro.2016.07.I2I

Khan, M., \& Damalas, C. A. (2015). Factors preventing the adoption of alternatives to chemical pest control among Pakistani cotton farmers. International Journal of Pest Management, 6I(I), 9-16. https://doi.org/10.1080/0967087 4.2014 .984257

Knight, K. E. (1967). A descriptive model of the intra-firm innovation process. The Journal of Business, 40, 478-496. https://doi.org/10.1086/295013

Lares-Orozco, M. F., Robles-Morúa, A., Yepez, E. A., \& Handler, R. M. (2016). Global warming potential of intensive wheat production in the Yaqui Valley, Mexico: a resource for the design of localized mitigation strategies. Journal of Cleaner Production, I27, 522-532. https://doi.org/10.1016/j.jclepro.2016.03.128

Lobell, D. B., Asner, G. P., Ortiz-Monasterio, J. I., \& Benning, T. L. (2003). Remote sensing of regional crop production in the Yaqui Valley, Mexico: estimates and uncertainties. Agriculture, Ecosystems Eo Environment, 94(2), 205-220. https://doi.org/10.1016/Sor67-8809(02)0002I-X

Luers, A. L., Lobell, D. B., Sklar, L. S., Addams, C. L., \& Matson, P. A. (2003). A method for quantifying vulnerability, applied to the agricultural system of the Yaqui Valley, Mexico. Global Environmental Change, I3(4), 255-267. https://doi.org/10.1016/S0959-3780(03)00054-2

Mardani, A., Nikoosokhan, S., Moradi, M., \& Doustar, M. (2018). The relationship between knowledge management and innovation performance. Journal of High Technology Management Research, 29(I), I2-26. https: //doi.org/ı.1016/j.hitech.2018.04.002

Marques, C. S., Marques, C. S., Leal, C., Leal, C., Marques, C. P., Marques, C. P., \& Cardoso, A. R. (20I6). Strategic knowledge management, innovation and performance: A qualitative study of the footwear industry. Journal of the Knowledge Economy, 7(3), 659-675. https://doi.org/10.1007/s13132-015-0249-4

Mejía. T, J., Sanchez. G, J., \& Maldonado, G., G. (2016). The Customer Knowledge Management and Innovation. An Empirical Study Using Structural Equations Model. Contaduría y Administración, 6I(3), 456-477. http:// dx.doi.org/I0.10I6/j.cya.2015.II.0II

Méndez-Barroso, L. A., Garatuza-Payán, J., \& Vivoni, E. R. (2008). Quantifying water stress on wheat using remote sensing in the Yaqui Valley, Sonora, Mexico. Agricultural Water Management, 95(6), 725-736. https://doi.org/ I0.1016/j.agwat.2008.01.016

Meza, M. M., Kopplin, M. J., Burgess, J. L., \& Gandolfi, A. J. (2004). Arsenic drinking water exposure and urinary excretion among adults in the Yaqui Valley, Sonora, Mexico. Environmental Research, 96(2), I19-126. https://d oi.org/10.1016/j.envres.2003.08.010

Meza-Montenegro, M. M., Gandolfi, A. J., Santana-Alcantar, M. E., Klimecki, W. T., Aguilar-Apodaca, M. G., del Rio-Salas, R., de la O-Villanueva, M., Gomez-Alvarez, A., Mendivil-Quijada, H., Valencia, M., \& MezaFigueroa, D. (2012). Metals in residential soils and cumulative risk assessment in Yaqui and Mayo agricultural valleys, northern Mexico. Science of the Total Environment, 433(I), 472-48I. https://doi.org/10.1016/j.scitotenv.2 012.06 .083 
Migdadi, M. M., Zaid, M. K. A., Yousif, M., Almestarihi, R., \& Al-Hyari, K. (2017). An empirical examination of knowledge management processes and market orientation, innovation capability, and organisational performance: Insights from jordan. Journal of Information \&o Knowledge Management, I6(I), 1750002. https://do i.org/I0.II42/So219649217500022

Millar, N., Urrea, A., Kahmark, K., Shcherbak, I., Robertson, G. P., \& Ortiz-Monasterio, I. (2018). Nitrous oxide $\left(\mathrm{N}_{2} \mathrm{O}\right)$ flux responds exponentially to nitrogen fertilizer in irrigated wheat in the Yaqui Valley, Mexico. Agriculture, ecosystems \& environment, 26I, I25-132. https://doi.org/I0.10I6/j.agee.2018.04.003

Moos, B., Beimborn, D., Wagner, H. T. and Weitzel, T. (2013). The role of knowledge management systems for innovation: an absorptive capacity perspective. International Journal of Innovation Management, I7(5), 13500I9I-I3500I931. https://doi.org/10.II42/S1363919613500199

Munyua, H., \& Stilwell, C. (2010). A mixed qualitative-quantitative-participatory methodology: a study of the agricultural knowledge and information system (AKIS) of small-scale farmers in Kirinyaga District, Kenya. Library management, 3I(I/2), 5-18. https://doi.org/10.1108/0I435121011013359

Nagano, M. S., \& Iacono, A. (2019). Knowledge management in eco-innovation practice: An analysis of the contribution of eco-innovation tools in the early stages of the product development process. Journal of Information E- Knowledge Management, I8(4), 1950047. https://doi.org/I0.II42/So219649219500473

Naqshbandi, M. M., \& Jasimuddin, S. M. (2018). Knowledge-oriented leadership and open innovation: Role of knowledge management capability in france-based multinationals. International Business Review, $27(3), 70 \mathrm{I}-713$. https://doi.org/I0.10I6/j.ibusrev.2017.I2.00I

Naylor, R. L., Falcon, W. P., \& Gonzalez, A. P. (200I). Policy Reforms and Mexican Agriculture: Views from the Yaqui Valley. CIMMYT.

Nonaka, I. and Takeuchi, H. (1995). The Knowledge-Creating Company: How Japanese Companies Create the Dynamics of Innovation. Oxford University Press.

Obeidat, B. Y., Al-Suradi, M. M., Masa'deh, R., \& Tarhini, A. (2016). The impact of knowledge management on innovation. Management Research Review, 39(I0), I2I4-I238. https://doi.org/I0.I108/MRR-09-2015-02I4

O’Brien, M. J. and Shennan, S. (2010). Innovation in Cultural Systems: Contributions from Evolutionary Anthropology. MIT Press.

Omoush, M. M. (2018). Impact knowledge management on innovation. field study on tourist agencies in irbid city, jordan. Human Geography Journal, 25(25), 75-80. https://doi.org/10.26565/2076-1333-2018-25-07

Organización para la Cooperación y el Desarrollo Económicos [OCDE]. (2005). Manual de Oslo: Guía para la recogida e interpretación de datos sobre innovación (tercera edición). EUROSTAT y OECD. https://doi.org/IO.I 787/9789264065659-es

Pavón M, J. and Goodman, R. A. (1976). Proyecto MODELTEC. La Planificación del Desarrollo Tecnológico: El Caso Español. CDTI y CSIC.

Polanyi, M. (1966). The logic of tacit inference. Philosophy, 4I(155), I-18. https://doi.org/10.1017/S0031819100066110

Rees, D. J., Momanyi, M., Wekundah, J., Ndungu, F., Odondi, J., Oyure, A. O., Andima, D., Kamau, M., Ndubi, J., Musembi, F., Mwaura, L., \& Joldersma, R. (2000). Agricultural knowledge and information systems in Kenya: implications for technology dissemination and development. Overseas development institute (ODI), Agricultural research \& extension network (AgREN).

Sadeghi Boroujerdi, S., Hasani, K., \& Delshab, V. (2019). Investigating the influence of knowledge management on organizational innovation in higher educational institutions. Kybernetes, 49(2), 442-459. https://doi.org/I $0.1108 / \mathrm{K}-09-2018-0492$ 
Saini, R., \& Bhargava, P. (2020). The role of knowledge management practices in sustaining innovation in SMEs of north india. IUP Journal of Knowledge Management, I8(I), 24-44.

Sánchez-Osorio, J. L., Macías-Zamora, J. V., Ramírez-Álvarez, N., \& Bidleman, T. F. (20I7). Organochlorine pesticides in residential soils and sediments within two main agricultural areas of northwest Mexico: Concentrations, enantiomer compositions and potential sources. Chemosphere, I73, 275-287. https://doi.org/I 0.1016/j.chemosphere.2017.01.010

Schumpeter, J. A. (1935). The analysis of economic change. The Review of Economics and Statistics, I7(4), 2-IO. https ://doi.org/10.2307/1927845

Servicio de Información Agroalimentaria y Pesquera [SIAP]. (2020). Avances de siembras y cosechas. Resumen por cultivo. Gobierno de México. Accessed june $6^{\text {th }}$, 2020 on http://infosiap.siap.gob.mx:8080/agricola_siap_gobmx/R esumenDelegacion.do

Shafique, M. (2013). Thinking inside the box? Intellectual structure of the knowledge base of innovation research (1988-2008). Strategic Management Journal, 34(I), 62-93. https://doi.org/10.1002/smj.2002

Singh, S. K., Gupta, S., Busso, D., \& Kamboj, S. (2019). Top management knowledge value, knowledge sharing practices, open innovation and organizational performance. Journal of Business Research, In Press. https://do i.org/10.1016/j.jbusres.2019.04.040

Suárez, B. A. (2012). La sanidad de los cultivos agrícolas, inversión trascendental en la agricultura del Valle del Yaqui. 2000 Agro, Revista Industrial del Campo.Accessed August 8 ${ }^{\text {th }}$, 2014). http://www.2000agro.com.mx/agro industria/la-sanidad-de-los-cultivos-agricolas-inversion-trascendental-en-la-agricultura-del-valle-del-yaqui/

Supermane, S. (2019). Transformational leadership and innovation in teaching and learning activities: The mediation effect of knowledge management. Information Discovery and Delivery, 47(4), 242-250. https://doi.or g/10.1108/IDD-05-2019-0040

Susanty, A. I., Yuningsih, Y., \& Anggadwita, G. (2019). Knowledge management practices and innovation performance. Journal of Science and Technology Policy Management, Io(2), 30I-318. https://doi.org/10.1108/JSTP $\mathrm{M}-03-2018-0030$

Techen, A. K., Helming, K., Brüggemann, N., Veldkamp, E., Reinhold-Hurek, B., Lorenz, M., ... Boy, J. (2020). Soil research challenges in response to emerging agricultural soil management practices. Advances in Agronomy, 17I, 179-24I. https://doi.org/10.1016/bs.agron.2020.01.002

Teixeira, E. K., Oliveira, M., \& Curado, C. M. M. (2018). Knowledge management process arrangements and their impact on innovation. Business Information Review, 35(I), 29-38 https://doi.org/I0.1177/026638211875777I

Tejedor, B., \& Aguirre, A. (1998). Proyecto logos: investigación relativa a la capacidad de aprender de las empresas españolas. Boletín de Estudios Económicos, 53(164), $23 \mathrm{I}-249$.

Totin, E., van Mierlo, B., \& Klerkx, L. (2020). Scaling practices within agricultural innovation platforms: Between pushing and pulling. Agricultural Systems, I79, 102764. https://doi.org/10.1016/j.agsy.2019.102764

Väyrynen, H., Helander, N., \& Vasell, T. (2017). Knowledge management for open innovation: Comparing research results between smes and large companies. International Journal of Innovation Management, 2I(5), 1740004. http s://doi.org/10.1142/S1363919617400047

Villa-Rodríguez, E., Parra-Cota, F., Castro-Longoria, E., López-Cervantes, J., \& de los Santos-Villalobos, S. (2019). Bacillus subtilis TE3: A promising biological control agent against Bipolaris sorokiniana, the causal agent of spot blotch in wheat (Triticum turgidum L. subsp. durum). Biological control, 132, 135-I43. https://doi.org/ I0.10I6/j.biocontrol.2019.02.0I2 
Wiig, K. M. (1993). Knowledge Management Foundations: Thinking About-How People and Organizations Create, Represent, and Use Knowledge. Schema.

Yousaf, M. J., \& Ali, Q. (2018). Impact of knowledge management on innovation: Evidence from a south asian country. Journal of Information \&o Knowledge Management, I7(3), I850035 https://doi.org/10.1142/So21964921850 035I

Zaltman, G., Duncan, R., \& Holbeck, J. (1973). Innovations and Organizations. John Wiley \& Sons. https://doi.org $/ 10.4236 /$ jep.2011.24038

\section{Notes}

* Research article Incorporation of New Full-Time Teachers (NPTC) from the Program for Teacher Professional Development (PRODEP), Program for Strengthening Educational Excellence (PROFEXCE), Program for Promotion and Support of Research (PROFAPI) of the Sonora Institute of Technology (ITSON).

CC BY 